\title{
Weathering in the Glacial Foreland of Southern and Western Greenland
}

\author{
Fabio Da Prat ${ }^{1}$ and Ellen Martin ${ }^{2}$ \\ $1^{2}{ }^{2}$ College of Liberal Arts and Sciences, University of Florida
}

Faculty mentor: Ellen Martin, Department of Geological Sciences

\begin{abstract}
Glaciers physically grind up underlying rock and create fine-grained sediment that has a high potential for chemical weathering. Subsequent weathering of these sediments produces solutes, including nutrients and radiogenic isotopes, which are transported by streams to the world's oceans where they can impact primary productivity and record past ice sheet activity. Previous research on the geochemistry of bedrock, bedload sediment and stream waters demonstrated that the extent of chemical weathering varies across a transect in western Greenland due to variations in either exposure age or precipitation, and that variations in the extent of weathering may affect marine records of past intervals of ice sheet retreat. This project adds a new study area in southern Greenland that has higher precipitation, more vegetation, a different lithology, and a range of exposure ages, to address the leading factors contributing to the extent of weathering. Based on the relative proportions of cations and differences between $\mathrm{Na}+\mathrm{K}$ concentrations of waters and bedload, the southern region is undergoing similar to more mature chemical weathering compared to the western transect, which suggests that lithology may be an important driver of weathering, and that exposure age and precipitation are less important factors. The results also highlight the need to investigate additional factors that contribute to weathering that were not accounted for in this study, such as dissolved organic matter and microbial activity.
\end{abstract}

\section{Introduction}

As glaciers move over bedrock, they enhance the physical weathering of the rock and produce abundant fine-grained material. The resulting high surface area to volume ratio increases the potential for chemical weathering of the sediment. Chemical weathering in high-latitude, glacial environments could serve as a long-term sink for CO2 (Anderson et al., 2000) and a source of nutrients and elements to the world's oceans (Scribner et al., 2015; Bhatia, et al., 2013). A dramatic increase in seawater $\mathrm{Pb}$ isotopes preserved in deep sea sediments from the last deglaciation ( $\sim 21,000$ to 11,000 years ago) has been interpreted as a record of intense chemical weathering of freshly exposed glacial sediment (Foster and Vance, 2006). The solutes produced by weathering were transferred to the ocean, incorporated into deep-sea sediments and preserve a history of ice sheet growth and decay. 
The glacial foreland spans from the edge of the ice sheet to the continental margin (Fig. 1). Supraglacial water originates from melting on top of the ice sheet. Subglacial water originates when water enters the ice sheet through moulins (vertical shafts in the ice sheet) or by melting within the ice and discharges from underneath the ice sheet. These supraglacial and subglacial waters combine to form proglacial rivers that carry the meltwater through proglacial watersheds to the ocean. In contrast, watersheds exposed by ice sheet retreat and now separated from the ice sheet by hydrologic divides are referred to as deglaciated watersheds (e.g. Fig. 2). The nonglacial streams in these watersheds originate from active layer melt and local precipitation and are not connected to the ice sheet meltwater system.

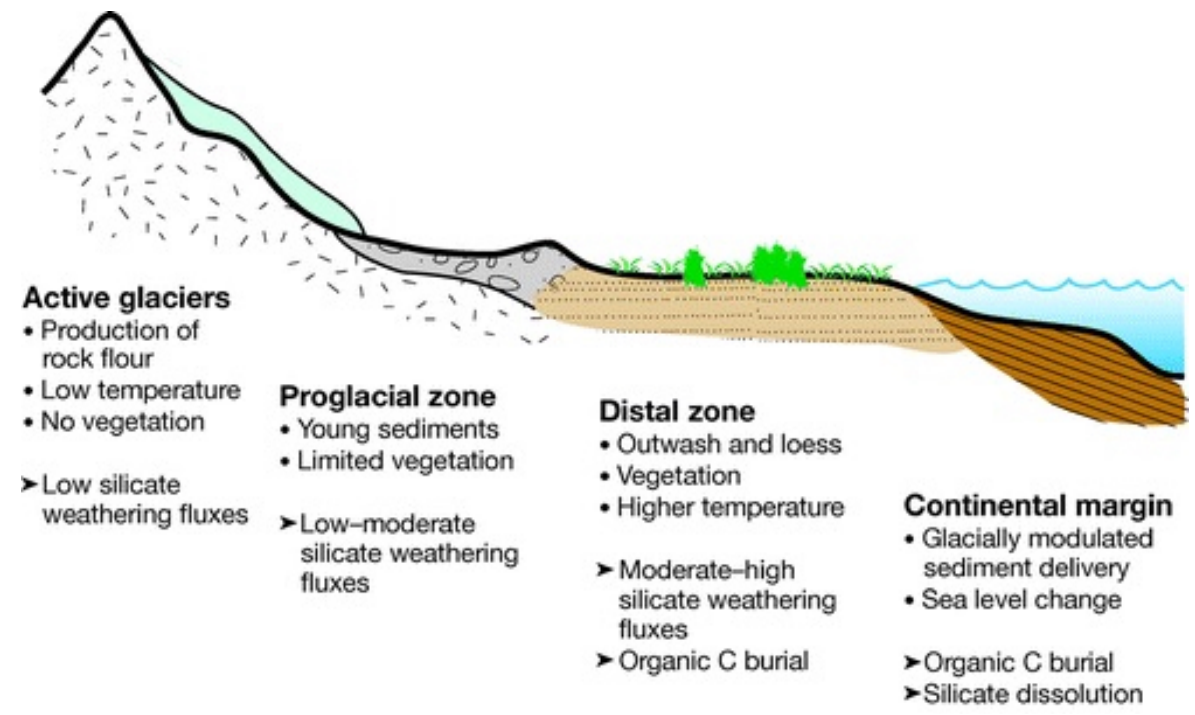

Figure 1. Simplified diagram of zones in the foreglacial environment. Sub- and supraglacial watersheds are associated with the active glacier. These waters feed into proglacial watersheds that transport ice melt to the ocean. Deglaciated watersheds are located in the distal zone that has been exposed by ice sheet retreat, and the associated non-glacial streams are sourced by local precipitation and active layer melt. Figure from Anderson, 2007.

Proglacial rivers have high total suspended solids and low total dissolved solids relative to non-glacial rivers (Wimpenny et al., 2010). These rivers contain a higher proportion of dissolved $\mathrm{Ca}^{2+}$ and $\mathrm{K}^{+}$ions because of subglacial weathering of trace carbonates and biotite as well as high SO42- ions from oxidation of trace sulfates that occurs under the ice sheet (Tranter, 2003; Wimpenny et al., 2010). Experimental studies demonstrated that chemical weathering of glacial sediments preferentially weathers carbonate and sulfate minerals before attacking silicate minerals (Anderson et al., 2000). Solute concentrations in proglacial rivers can increase downstream as the waters interact with and chemically weather bedload material, thus they are sensitive recorders of weathering reactions. 
The extent or maturity of chemical weathering is a reflection of how much the chemistry of the rocks and sediments in a region have been altered by reaction with water that result in dissolution or alteration of the minerals in the solid phase. Due to the high concentrations of elements in the rock and the minor chemical changes produced by chemical weathering, it is often difficult to evaluate weathering by studying solid phases. In contrast, the chemistry of the water can change dramatically with the addition of solutes from weathering reactions.

There are a variety of factors including lithology, exposure age, precipitation, climate, and vegetation that can affect the extent of chemical weathering reactions in a particular region. Bedrock composition, or lithology, determines the minerals that are available for reaction, and some minerals are more reactive than others due to differences in bond strengths within the mineral. The availability of water and temperature determine the rate of reactions, a warmer climate is more conducive to chemical weathering than a more temperate climate under the same conditions. Vegetation, also governed by climate and precipitation, breaks down sediments into soil, that have smaller particle sizes and more organic matter that drive weathering reactions. Plant respiration also produces $\mathrm{CO}_{2}$, some of which is released into the soil and drives chemical weathering. This study focuses on a comparison of $\mathrm{Si}^{4+}, \mathrm{Mg}^{2+}, \mathrm{Ca}^{2+}, \mathrm{Na}^{+}$, and $\mathrm{K}^{+}$in bedload sediment and streamwater, since these are common cations released by the weathering of a wide range of silicate and carbonate minerals. The reactions below illustrate the $\mathrm{CO}_{2}$ uptake and weathering solutes produced by typical silicate (R1 and R2) and carbonate (R3) reactions:

$$
\begin{aligned}
& \text { R1: }(\mathrm{Na}, \mathrm{K}) \mathrm{AlSi}_{3} \mathrm{O}_{8}+\mathrm{CO}_{2}+5.5 \mathrm{H}_{2} \mathrm{O} \leftrightarrow\left(\mathrm{Na}^{+}, \mathrm{K}^{+}\right)+\mathrm{HCO}_{3}^{-}+0.5 \mathrm{Al}_{2} \mathrm{Si}_{2} \mathrm{O}_{5}(\mathrm{OH})_{4}+2 \mathrm{H}_{4} \mathrm{SiO}_{4} \\
& \text { R2: }(\mathrm{Ca}, \mathrm{Mg}) \mathrm{Al}_{2} \mathrm{Si}_{2} \mathrm{O}_{8}+2 \mathrm{CO}_{2}+3 \mathrm{H}_{2} \mathrm{O} \leftrightarrow\left(\mathrm{Ca}^{2+}, \mathrm{Mg}^{2+}\right)+2 \mathrm{HCO}_{3}^{-}+\mathrm{Al}_{2} \mathrm{Si}_{2} \mathrm{O}_{5}(\mathrm{OH})_{4} \\
& \text { R3: } \mathrm{CaCO}_{3}+\mathrm{CO}_{2}+\mathrm{H}_{2} \mathrm{O} \leftrightarrow \mathrm{Ca}^{2+}+2\left(\mathrm{HCO}_{3}^{-}\right)
\end{aligned}
$$

Silicate minerals tend to have stronger bonds and be more resistant to chemical weathering than carbonate minerals. As a result, weathering solutes are often initially dominated by carbonate sources and then transition to silicate sources with more extensive weathering. This study will examine the weathering maturity of each watershed, as it is reflected by changes in major element compositions of the water relative to the bedload and bedrock compositions. 


\section{Study Areas}

Melting of the Greenland Ice Sheet (GrIS) over the past 10,000 years exposed a transect of fresh sediments along the margin of western and southern Greenland (Fig. 1 and 2). In the western transect, exposure ages of the deglaciated watersheds increase in age from $\sim 7$ ka to $\sim 10$ ka with increasing distance from the ice (Scribner et al., 2015). There are also Little Ice Age moraines ( 200 yrs) adjacent to the GrIS in some areas. The entire western transect is underlain by the Nagsugtiqidian Mobile Belt (NMB) (Fig. 2A) composed of metamorphosed granodiorites and tonalitic orthgneisses (1.7-1.9 Ga) formed from rocks of the Archean Belt (AB-2.6-3.1 Ga; White et al., 2016). There is also a precipitation gradient across the transect that ranges from 150 $\mathrm{mm} /$ year near the ice to $350 \mathrm{~mm} /$ year at the coast (Fig. 2B). As a result, the inland vegetation is sparse, mostly composed of tundra and small shrubs. The western Greenland transect thus serves as an exceptional location to understand how exposure age, lithology, and climate affect chemical weathering of sediments in glacial settings. In comparison to the western transect, the southern region has a more variable lithology (Fig. 2A), which includes the Ketilidian Mobile Belt (KMB), and the Gardar Province. The KMB ( 1.9-1.7 Ga) underlies most of the southern region and is composed of granitoids and low- to high-grade metasediments (White et al., 2016). The Gardar Province, which is composed of alkaline basalts and sandstones (1.35-1.12 Ga) makes up the southern-most part of the study area (Paslick, 1993). The southern region also has higher annual precipitation $(900 \mathrm{~mm} /$ year $)$, a warmer climate $\left(\sim 5^{\circ} \mathrm{C}\right.$ higher; Danish Meteorological Institute), a wide range of exposure ages ( 10 to $\sim 1.5 \mathrm{ka}$ ) (Fig. $2 \mathrm{C}$ ), and more vegetation in some areas, including trees and larger bushes.

Scribner et al., (2015) described the differences in weathering across the deglaciated watersheds in the western transect and divided them into 1) coastal deglaciated watersheds that were located in older moraines, exposed to a positive water balance, and exhibited more extensive weathering based on solute concentrations and $\mathrm{Sr}$ isotopes, and 2) inland deglaciated watersheds located in younger moraines with a negative water balance and less extensive weathering. Deuerling (2016) used a mass balance model with stream solutes to identify carbonate versus silicate mineral weathering and carbonic $\left(\mathrm{H}_{2} \mathrm{CO}_{3}\right)$ versus sulfuric $\left(\mathrm{H}_{2} \mathrm{SO}_{4}\right)$ weathering acids. They demonstrated that the water compositions reflect a shift from predominantly carbonate weathering inland to predominately silicate weathering near the coast, and that the proportion of weathering by sulfuric acid increases toward the coast (Fig. 3). These 
changes in weathering are accompanied by a decrease in the offset between dissolved and bedload $\mathrm{Sr}$ isotope ratios, and are again interpreted to indicate more mature weathering closer to the coast with increasing exposure age and precipitation.

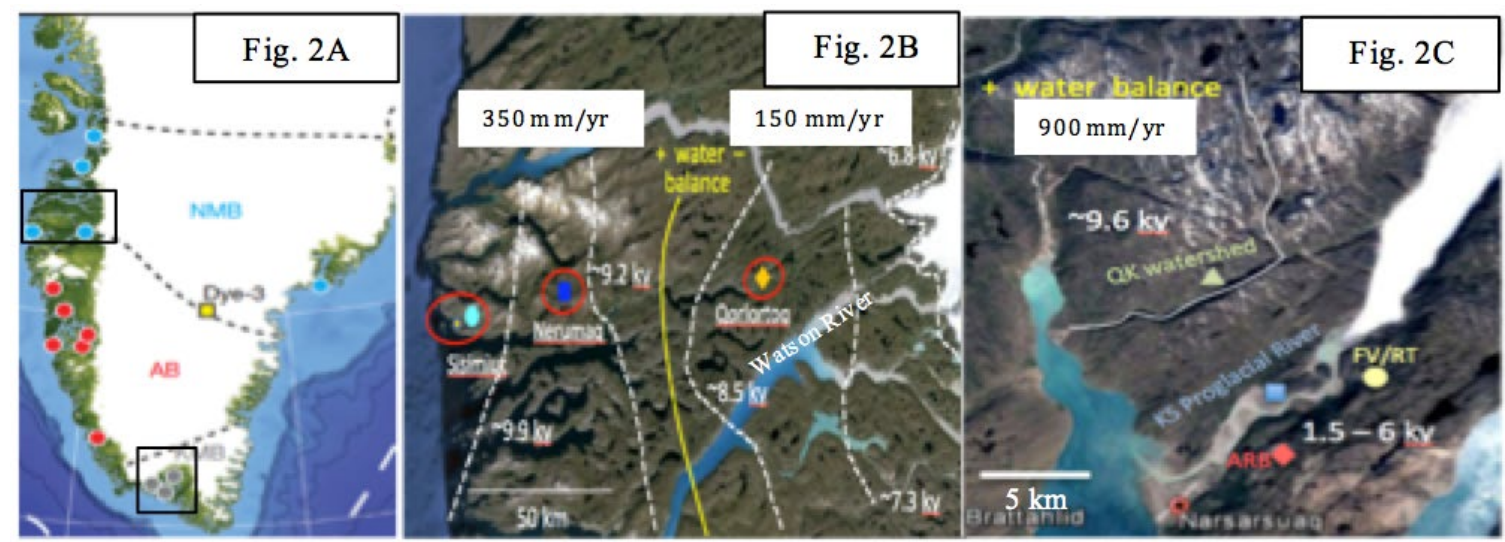

Figure 2. Fig. 2A) Map of Greenland illustrating the major lithological provinces that were analyzed in this study. $\mathrm{NBM}=$ Nagsugtiqidian Mobile Belt, $\mathrm{AB}=$ Archean Block, $\mathrm{KMB}=$ Ketilidian Mobile Belt. Figure modified from

Reyes et al. (2014). 2B) Map of western study area showing the locations of Nerumaq, Qorlortoq, and Watson River watersheds that form a transect of increasing weathering maturity from the ice sheet to the coast (Scribner et al., 2015). 2C) Map of southern study area near Narsarsuaq showing location of five sampled watersheds: Qornup Kuua (QK), Flower Valley (FV), Rope trail (RT) and Arboritum (ARB) are deglaciated watersheds. Kiagtut Sermia $(\mathrm{KS})$ is a proglacial river. White text represents exposure ages of moraines in each watershed. Yellow text and white boxes represent precipitation information.

This study will evaluate the differences in the extent of weathering maturity between the western transect and southern region, as well as within the southern region, by comparing the major element chemistry of water, bedload, and bedrock. The bedload and bedrock data for the western transect come from a study by Collazo et al. (2015) that evaluated a coastal deglaciated watershed (Nerumaq), an inland deglaciated watershed (Qorlortoq), and a proglacial system (Watson River; WR). The new data from the southern regions include five deglacial watersheds: Qornup Kuua (QK), Flower Valley (FV), Rope Trail (RT) and Arboritum (ARB), and one proglacial watershed that drains the Kiagut Sermia (KS) (Fig. 2). The bedload samples are believed to represent an integrated composition of bedrock sources in each watershed, and therefore may provide a more accurate record of specific contributions to the watershed. The western water data come from a study by Scribner et al., (2015) and represent a sensitive monitor of weathering reactions. The goal of this study is to compare previous chemical data on bedload, bedrock and dissolved solutes in the water from watersheds in the western transect to the geochemistry in the southern region near Narsarsuaq to understand how precipitation, exposure age, rock type, and vegetation impact chemical weathering of rocks and ultimately the composition of river runoff transported to the ocean. 


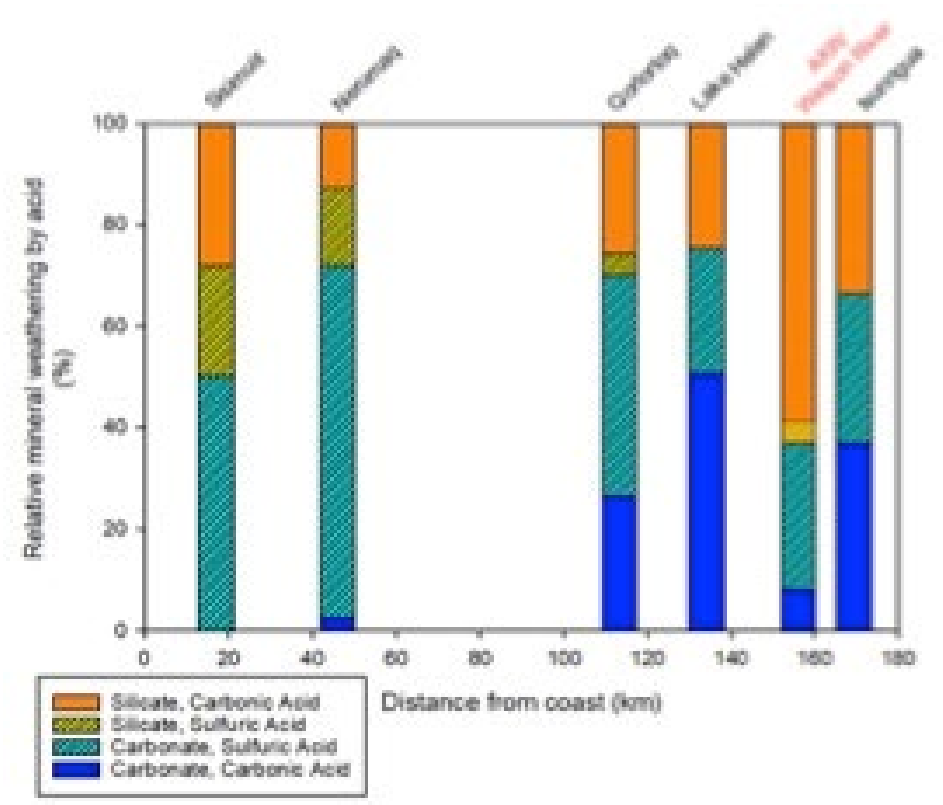

Figure 3. Calculated average relative abundances of chemical weathering divided by mineralogy and acid. Silicate mineral weathering (warm colors) and carbonate mineral weathering (cool colors), carbonic acid (plain pattern) and sulfuric acid (hatched pattern). Names of areas are listed above the bars: black text represents non-glacial streams; red text indicates the proglacial streams draining the entire Watson River watershed. (From Deuerling, 2016)

\section{Methods}

\section{Sample Collection}

All solid samples were collected in the region of Narsarsuaq, Greenland during August-

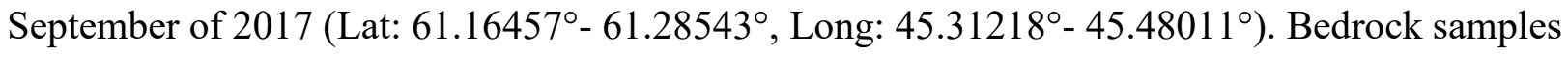
were collected from outcrops near the bedload sample sites and were selected to provide a suite of the different lithological units found in the study area; however, the limited number of bedrock samples clearly do not encompass all of the regional lithologies, particularly lithologies that are now under the ice sheet. Bedload samples were collected at each site where waters were sampled using a plastic trowel or gloved hand and stored in zip-lock bags. Regolith samples were not collected as part of this study, due to the sparse availability of regolith in most sampling locations. Suspended load was only collected in proglacial rivers, but quantities were small and are being used for isotopic studies.

Water was pumped from the center of river channels through an overflow cup using tygon tubing attached to a Geotech II $12-\mathrm{V}$ peristaltic pump located on riverbanks. Water was filtered through a $0.45 \mu \mathrm{m}$ trace metal grade canister filter and collected in sample-appropriate containers after triple rinsing with sample water. Cation $(20 \mathrm{ml})$ samples were collected in acid 
washed HDPE bottles and acidified to $\mathrm{pH}<2$ with optima grade nitric acid. The acidification of water samples took place in a laboratory at Kangerlussuaq International Science Station. All samples were chilled and shipped to the University of Florida within one month of collection.

\section{Sample Preparation}

Bedload and bedrock samples were prepared for XRF analyses by crushing, then grinding the samples into a fine powder. Bedload samples were sieved to remove the $>2 \mathrm{~mm}$ size fraction to avoid any single large grain dominating the analysis. Approximately $1.5 \mathrm{~g}$ of fine rock powder underwent loss on ignition (LOI) at about $1000^{\circ} \mathrm{C}$ for an hour, and LOI was calculated to be, on average, $0.99 \%$ of the sample weight. After LOI, one gram $( \pm 0.005)$ of sample was mixed with 6 $( \pm 0.005)$ grams of lithium metaborate flux in order to make glass disks using a Katanax fusion machine.

\section{Sample Analysis}

The bedload and bedrock samples were analyzed for major elements $\left(\mathrm{SiO}_{2}, \mathrm{TiO}_{2}, \mathrm{Al}_{2} \mathrm{O}_{3}\right.$, $\mathrm{Fe}_{2} \mathrm{O}_{3}, \mathrm{MnO}, \mathrm{MgO}, \mathrm{CaO}, \mathrm{Na}_{2} \mathrm{O}$, and $\mathrm{K}_{2} \mathrm{O}$ ) using a Rigaku "supermini” model wavelengthdispersive $\mathrm{x}$-ray fluorescence. Precision is $\pm 1 \%$ for most element oxides and $\pm 5 \%$ for $\mathrm{Na}_{2} \mathrm{O}$. Oxides were summed to $100 \pm 1 \%$ to assess precision of the data. Percent oxides were converted to $\mathrm{Si}, \mathrm{Ca}, \mathrm{Mg}, \mathrm{Na}$ and $\mathrm{K}$ concentrations in $\mathrm{mM}$ for comparison with dissolved solutes using gram formula weights for each oxide.

Major ion concentrations were analyzed on undiluted water samples using a Dionex Model 500DX Ion Chromatograph and in-house multi-element standards. Precision was $<5 \%$ based on an internal standard measured every five samples. All samples had charge balance errors $<20 \%$ with $85 \%$ of the samples having $<10 \%$ charge balance error; samples with large errors had low ionic strengths. Si concentrations on water samples were analyzed using a Thermo Fischer Element 2 Inductively Coupled Plasma Mass Spectrometer (ICP-MS). Dried water samples were dissolved with a trace metal grade nitric acid and analyzed using a $\mathrm{Re} / \mathrm{Rh}$ internal standard and a SLRS-4 reference standard.

\section{Results}

Bedrock composition in the southern region (Table 1) is highly variable and ranges from granites to syenitic rocks (Fig. 4A). Only 4 bedrock samples from the western region (Table 2) were analyzed by Collazo et al. (2015). These samples range from syenitic to gabbroic rocks; however, these are unlikely to represent the entire range of compositions for this region. 
Consistent with these mapped lithologies (White et al., 2016), southern region bedrock samples have a higher overall percent silica than western transect bedrock samples (Fig. 4). Bedload (Table 3 ) for the southern region is mainly syenitic in composition, varying from nepheline syenites to syeno-granites, while the bedload for the western region (Table 4) plots as diorites, granodiorites, and granites (Fig. 4B). Bedload compositions for both regions fall between the bedrock compositions of the region, although this trend is not as well defined for the western transect, due to the limited number of samples.

Table 1. Whole-rock chemistry of southern bedrock samples (relative percent)

\begin{tabular}{cccccccccc}
\hline Sample Name & $\mathrm{SiO}_{2}$ & $\mathrm{TiO}_{2}$ & $\mathrm{Al}_{2} \mathrm{O}_{3}$ & $\mathrm{Fe}_{2} \mathrm{O}_{3}$ & $\mathrm{MnO}$ & $\mathrm{MgO}$ & $\mathrm{CaO}$ & $\mathrm{Na}_{2} \mathrm{O}$ & $\mathrm{K}_{2} \mathrm{O}$ \\
\hline NA-ARB-N-2 & 69.02 & 0.44 & 15.50 & 2.51 & 0.08 & 0.23 & 0.61 & 5.38 & 6.14 \\
NA-ARB-S-2 & 72.22 & 0.24 & 14.60 & 1.77 & 0.02 & 0.68 & 0.51 & 5.57 & 4.85 \\
NA-ARB-N-1 & 73.29 & 0.13 & 14.41 & 1.47 & 0.03 & 1.42 & 0.18 & 2.85 & 6.22 \\
NA-ARB-N-1 & 74.11 & 0.13 & 14.58 & 1.64 & 0.03 & 1.41 & 0.18 & 2.85 & 6.32 \\
Pink cornflake & 60.27 & 0.22 & 21.05 & 5.40 & 0.20 & 0.10 & 0.00 & 5.99 & 6.64 \\
White cornflake & 59.57 & 0.22 & 18.88 & 6.99 & 0.29 & 0.24 & 1.13 & 6.48 & 5.59 \\
NA-RT-Lake & 66.58 & 0.43 & 17.40 & 3.33 & 0.06 & 1.01 & 2.44 & 5.15 & 4.09 \\
NA-RT-2 & 69.52 & 0.22 & 16.33 & 2.92 & 0.10 & 0.60 & 0.71 & 4.85 & 4.89 \\
NA-RT-2 dike & 58.58 & 1.04 & 14.8 & 11.45 & 0.23 & 0.60 & 2.91 & 5.68 & 5.16 \\
FV road syenite & 71.40 & 0.24 & 13.34 & 2.46 & 0.04 & 0.10 & 3.33 & 7.32 & 0.93 \\
NA-FA-7 & 66.18 & 0.48 & 17.48 & 3.58 & 0.07 & 0.99 & 2.51 & 5.70 & 3.30 \\
NA Sample near bench & 62.65 & 0.46 & 18.66 & 3.44 & 0.07 & 0.95 & 3.01 & 7.57 & 2.86 \\
Bench site near NARS & 57.14 & 0.36 & 21.31 & 6.05 & 0.19 & 0.4 & 0.75 & 4.15 & 9.37 \\
NARS bench & 62.68 & 0.48 & 18.78 & 3.31 & 0.05 & 0.86 & 2.95 & 7.57 & 2.89 \\
NA-QK-1-A & 61.37 & 0.63 & 16.21 & 4.70 & 0.08 & 3.33 & 2.86 & 6.03 & 4.13 \\
NA-QK-1-B & 57.11 & 0.77 & 15.61 & 7.78 & 0.1 & 5.69 & 5.09 & 4.30 & 4.16 \\
Outcrop below north slope & 75.15 & 0.17 & 13.33 & 1.55 & 0.01 & 0.17 & 0.50 & 4.62 & 5.07 \\
between QK-2 and QK-3 & & & & & & & & \\
NA-QK-GS & 68.98 & 0.30 & 16.26 & 2.73 & 0.05 & 0.68 & 2.70 & 5.00 & 3.48 \\
KS1 sandstone & 59.75 & 0.38 & 14.09 & 3.64 & 0.10 & 6.98 & 8.46 & 2.87 & 4.26 \\
KS1 boulder & 64.99 & 0.43 & 16.24 & 3.73 & 0.07 & 1.35 & 2.62 & 3.92 & 4.86 \\
NARS harbor & 47.74 & 1.86 & 17.46 & 14.83 & 0.18 & 6.90 & 8.83 & 2.67 & 0.84 \\
\hline
\end{tabular}

Table 2. Whole-rock chemistry of western bedrock samples (relative percent, data from Collazo et al., 2015)

\begin{tabular}{cccccccccc}
\hline Sample Name & $\mathrm{SiO}_{2}$ & $\mathrm{TiO}_{2}$ & $\mathrm{Al}_{2} \mathrm{O}_{3}$ & $\mathrm{Fe}_{2} \mathrm{O}_{3}$ & $\mathrm{MnO}$ & $\mathrm{MgO}$ & $\mathrm{CaO}$ & $\mathrm{Na}_{2} \mathrm{O}$ & $\mathrm{K}_{2} \mathrm{O}$ \\
\hline N1-M1 & 66.82 & 0.50 & 15.93 & 5.20 & 0.08 & 2.43 & 5.29 & 4.11 & 1.27 \\
N1-M2 & 66.45 & 0.60 & 15.7 & 5.47 & 0.09 & 2.67 & 5.36 & 3.94 & 1.35 \\
N1-M3 & 57.53 & 0.87 & 14.74 & 12.66 & 0.29 & 3.57 & 5.26 & 2.88 & 1.51 \\
N1-M4 & 65.92 & 0.50 & 13.72 & 5.73 & 0.09 & 2.7 & 5.02 & 3.51 & 1.26 \\
$\mathrm{Q} 1-M 1$ & 69.64 & 0.64 & 14.1 & 5.33 & 0.10 & 1.81 & 4.45 & 3.86 & 1.47 \\
$\mathrm{Q} 1-M 4$ & 62.88 & 0.88 & 15.19 & 7.48 & 0.12 & 2.84 & 5.15 & 3.56 & 1.94 \\
$\mathrm{Q} 2-M 2$ & 67.56 & 0.77 & 14.4 & 5.91 & 0.10 & 2.1 & 4.85 & 3.70 & 1.57 \\
WR 8-1 & 64.95 & 0.69 & 14.75 & 7.22 & 0.10 & 2.73 & 5.24 & 3.86 & 1.30 \\
WR 9-1 & 73.27 & 0.37 & 13.21 & 3.69 & 0.06 & 1.31 & 3.66 & 3.76 & 1.77 \\
\hline
\end{tabular}


Table 3. Whole-rock chemistry of southern bedload samples (relative percent)

\begin{tabular}{cccccccccc}
\hline Sample Name & $\mathrm{SiO}_{2}$ & $\mathrm{TiO}_{2}$ & $\mathrm{Al}_{2} \mathrm{O}_{3}$ & $\mathrm{Fe}_{2} \mathrm{O}_{3}$ & $\mathrm{MnO}$ & $\mathrm{MgO}$ & $\mathrm{CaO}$ & $\mathrm{Na}_{2} \mathrm{O}$ & $\mathrm{K}_{2} \mathrm{O}$ \\
\hline NA-ARB-N-2 & 61.03 & 0.20 & 19.43 & 4.29 & 0.17 & 0.21 & 0.49 & 6.99 & 6.42 \\
NA-ARB-S-2 & 61.51 & 1.47 & 15.58 & 8.36 & 0.12 & 1.92 & 3.46 & 4.56 & 3.57 \\
NA-ARB-S-1 & 63.21 & 0.92 & 15.80 & 6.20 & 0.13 & 1.78 & 3.00 & 5.00 & 4.16 \\
NA-ARB-Mix & 60.76 & 1.11 & 14.87 & 10.42 & 0.21 & 1.10 & 2.49 & 5.15 & 3.83 \\
NA-FV-1 & 67.60 & 0.54 & 15.74 & 3.71 & 0.08 & 0.94 & 1.87 & 4.76 & 4.55 \\
NA-FV-2 & 66.60 & 0.71 & 15.17 & 4.43 & 0.07 & 1.46 & 3.02 & 4.48 & 4.21 \\
NA-RT-Lake & 66.68 & 0.56 & 16.63 & 3.92 & 0.06 & 1.09 & 2.04 & 4.92 & 4.36 \\
NA-RT-1 & 65.00 & 1.05 & 14.85 & 7.38 & 0.07 & 1.36 & 2.80 & 4.53 & 3.53 \\
NA-RT-2 & 66.47 & 0.64 & 16.47 & 3.95 & 0.06 & 1.32 & 2.85 & 5.08 & 3.85 \\
NA-RT-2 Aeolian & 65.88 & 0.68 & 15.51 & 4.20 & 0.07 & 1.52 & 3.00 & 4.67 & 4.43 \\
NA-QK-1 & 62.52 & 0.76 & 16.44 & 5.66 & 0.09 & 2.46 & 3.96 & 4.66 & 3.82 \\
NA-QK-4 & 62.49 & 0.59 & 17.68 & 5.30 & 0.11 & 2.16 & 3.78 & 4.72 & 3.75 \\
NA-QK-GS & 63.61 & 0.91 & 15.86 & 6.39 & 0.08 & 2.09 & 3.39 & 4.27 & 3.72 \\
NA-QK-5 & 58.73 & 1.33 & 15.65 & 9.08 & 0.12 & 3.51 & 4.56 & 4.53 & 3.61 \\
KS1 Coarse & 63.36 & 0.97 & 15.01 & 6.31 & 0.07 & 1.54 & 3.36 & 4.52 & 3.83 \\
KS1 Fine & 64.81 & 0.93 & 14.84 & 5.85 & 0.08 & 1.46 & 3.37 & 4.43 & 3.98 \\
KS1 Fine Tidal & 56.61 & 0.85 & 14.18 & 16.73 & 0.13 & 1.63 & 2.74 & 4.03 & 3.55 \\
KS3 & 62.42 & 1.38 & 15.93 & 7.14 & 0.09 & 1.82 & 3.21 & 4.81 & 3.80 \\
KS4 & 63.02 & 0.85 & 16.98 & 5.21 & 0.09 & 1.82 & 3.44 & 4.90 & 4.00 \\
\hline
\end{tabular}

Table 4. Whole-rock chemistry of western bedload samples (relative percent, data from Collazo et al., 2015)

\begin{tabular}{cccccccccc}
\hline Sample Name & $\mathrm{SiO}_{2}$ & $\mathrm{TiO}_{2}$ & $\mathrm{Al}_{2} \mathrm{O}_{3}$ & $\mathrm{Fe}_{2} \mathrm{O}_{3}$ & $\mathrm{MnO}$ & $\mathrm{MgO}$ & $\mathrm{CaO}$ & $\mathrm{Na}_{2} \mathrm{O}$ & $\mathrm{K}_{2} \mathrm{O}$ \\
\hline SIS 3B & 55.28 & 1.27 & 19.11 & 8.94 & 0.07 & 2.72 & 4.00 & 3.53 & 5.42 \\
SIS 3A & 56.56 & 0.93 & 18.75 & 6.22 & 0.08 & 3.15 & 5.00 & 3.31 & 5.81 \\
SIS 4 & 52.47 & 0.87 & 9.92 & 13.63 & 0.26 & 14.22 & 7.66 & 1.7 & 1.61 \\
Kanger 1 & 62.72 & 0.58 & 17.84 & 4.41 & 0.06 & 1.56 & 4.68 & 4.13 & 3.84 \\
\hline
\end{tabular}

Table 5. Concentrations of $\mathrm{Na}^{+}, \mathrm{K}^{+}, \mathrm{Mg}^{2+}, \mathrm{Ca}^{2+}$, and $\mathrm{Si}^{4+}$ for southern water samples (mmol, $\mathrm{Cl}^{-}$corrected)

\begin{tabular}{cccccc}
\hline Sample Name & $\mathrm{Na}^{+}$ & $\mathrm{K}^{+}$ & $\mathrm{Mg}^{2+}$ & $\mathrm{Ca}^{2+}$ & $\mathrm{Si}^{4+}$ \\
\hline NA-ARB-N-2 & 0.1133693 & 0.01531549 & 0.00570717 & 0.14110603 & 0.074211773 \\
NA-ARB-S-1 & 0.0857409 & 0.00647337 & 0.00746921 & 0.14986239 & 0.053165944 \\
NA-ARB-S-2 & 0.0830383 & 0.00674719 & 0.00883327 & 0.15413593 & 0.036442041 \\
NA-FV-1 & 0.0861272 & 0.01626696 & 0.01819368 & 0.15895912 & 0.047629246 \\
NA-FV-2 & 0.0728754 & 0.03448922 & 0.01773226 & 0.16807734 & 0.033078443 \\
NA-RT-1 & 0.0373374 & 0.01092582 & 0.02158006 & 0.19091754 & 0.046743128 \\
NA-RT-2 & 0.041163 & 0.0123959 & 0.0223247 & 0.1939873 & - \\
KS1 & 0.0133484 & 0.01516812 & 0.01389596 & 0.08766564 & 0.001334378 \\
KS2 & 0.0084727 & 0.01522511 & 0.01097263 & 0.09262217 & 0.011421274 \\
KS3 & 0.0144304 & 0.01773072 & 0.01430176 & 0.11852784 & 0.020919149 \\
KS4 & 0.032527 & 0.0185211 & 0.0151363 & 0.1304117 & 0.023323848 \\
NA-QK-1 & 0.0051573 & 0.00291389 & 0.01191437 & 0.05171083 & - \\
NA-QK-2 & 0.0080226 & 0.00285218 & 0.00949394 & 0.04324846 & 0.003343706 \\
NA-QK-3 & 0.0096597 & 0.00399421 & 0.01439293 & 0.05468987 & 0.007566381 \\
NA-QK-4 & 0.030507 & 0.0070951 & 0.0512783 & 0.2417897 & 0.013523359 \\
NA-QK-5 & 0.0117738 & 0.00479234 & 0.01888322 & 0.07078798 & 0.011204962 \\
NA-QK-GS & 0.0146723 & 0.00553339 & 0.03205787 & 0.12092733 & 0.020705267 \\
\hline
\end{tabular}


Table 6. Concentrations of $\mathrm{Na}^{+}, \mathrm{K}^{+}, \mathrm{Mg}^{2+}, \mathrm{Ca}^{2+}$, and $\mathrm{Si}^{4+}$ for western water samples (mmol, $\mathrm{Cl}^{-}$corrected, data from Scribner et al., 2015)

\begin{tabular}{cccccc}
\hline Sample Name & $\mathrm{Na}^{+}$ & $\mathrm{K}^{+}$ & $\mathrm{Mg}^{2+}$ & $\mathrm{Ca}^{2+}$ & $\mathrm{Si}^{4+}$ \\
\hline Watson River: & & & & & \\
WR 8-2 & 0.0020525 & 0.00465325 & 0.00485725 & 0.01575275 & 0.0083 \\
WR 10-2 & 0.0072089 & 0.01034577 & 0.00871841 & 0.03384519 & 0.012 \\
WR 11-2 & 0.0121627 & 0.01231211 & 0.00824363 & 0.02971117 & 0.0123 \\
WR 6-2 & 0.0247204 & 0.01741772 & 0.00847276 & 0.03551684 & 0.0176 \\
WR 2-2 & 0.0251627 & 0.01791211 & 0.00874363 & 0.03731117 & 0.0173 \\
WR-KISS-2 & 0.0253486 & 0.01811398 & 0.00865334 & 0.03741306 & 0.0173 \\
Nerumaq: & & & & & \\
N1-M1 & 0.05692 & 0.017756 & 0.148348 & 0.257732 & 0.026 \\
N1-M2 & 0.05692 & 0.017756 & 0.158348 & 0.277732 & 0.0859 \\
N1-M3 & 0.05692 & 0.017756 & 0.138348 & 0.247732 & 0.0433 \\
N1-M4 & 0.05551 & 0.017943 & 0.119319 & 0.197921 & 0.0639 \\
N1-M5 & 0.06551 & 0.017943 & 0.119319 & 0.177921 & 0.1072 \\
Qorlortoq: & & & & & \\
Q1-M1 & 0.0865275 & 0.09844075 & 0.24744475 & 0.35906525 & 0.0070 \\
Q1-M2 & 0.0771284 & 0.09342212 & 0.26297796 & 0.37330364 & 0.0047 \\
Q1-M3 & 0.072786 & 0.0940198 & 0.3072734 & 0.4280906 & 0.0097 \\
Q1-M4 & -0.0593079 & 0.09539353 & 0.35079849 & 0.48076191 & 0.0093 \\
\hline
\end{tabular}
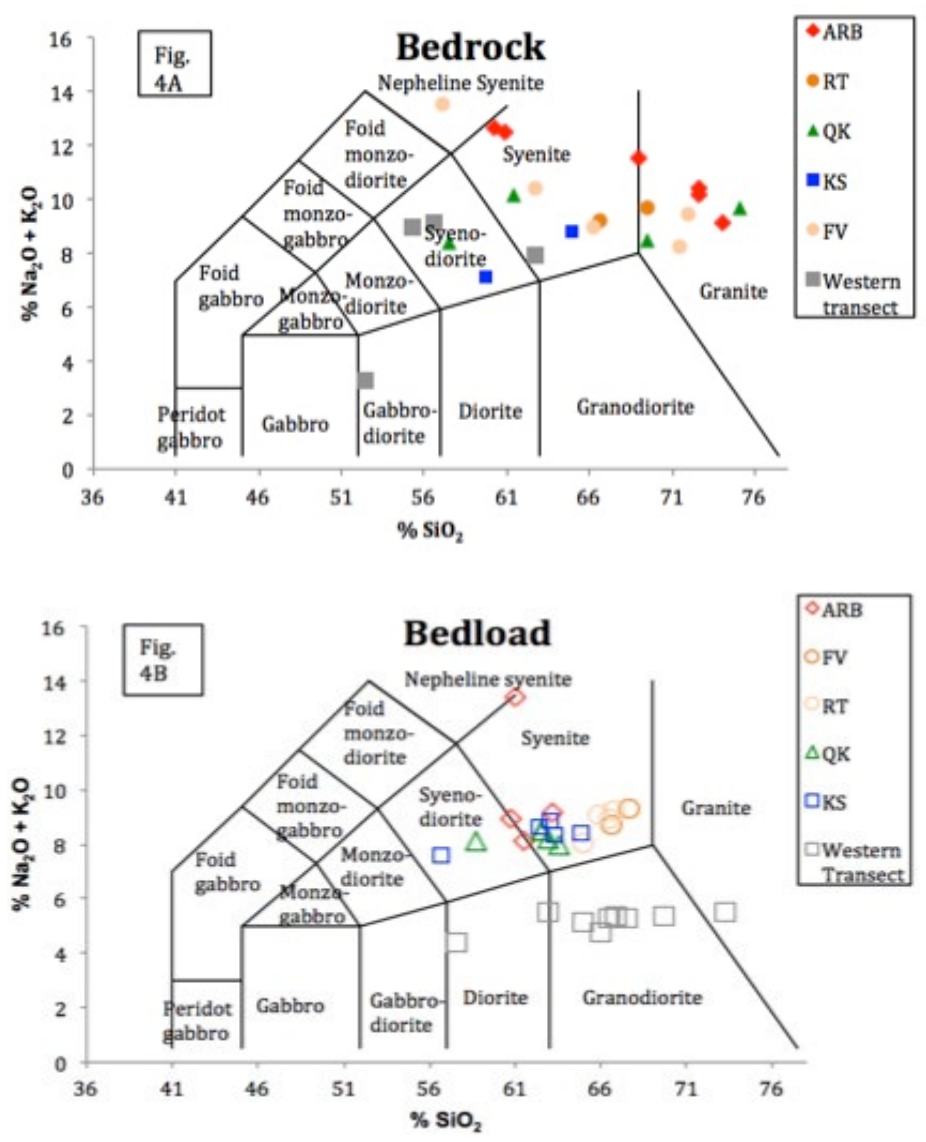

Figure 4. Total alkali-silica diagram used to identify: A) bedrock compositions, and B) bedload compositions, in southern and western study areas. 
The southern bedrock and bedload tend to have higher relative proportions of $\mathrm{Na}+\mathrm{K}$ and lower $\mathrm{Ca} / \mathrm{Mg}$ than western bedload and bedrock samples (Fig. 5). ARB and FV/RT solid and water samples plot closest to the $\mathrm{Na}+\mathrm{K}$ apex, while QK and $\mathrm{KS}$ samples plot farthest from the $\mathrm{Na}+\mathrm{K}$ apex (Fig. 6A). Compared to the bedload and bedrock, the major element chemistry of waters in the southern region (Table 5) has lower proportions of $\mathrm{Na}+\mathrm{K}$ and higher ratios of $\mathrm{Ca} / \mathrm{Mg}$ (Fig. 6A). The western transect waters (Table 6) also have lower proportions of $\mathrm{Na}+\mathrm{K}$ compared to the bedload and bedrock. The relative proportions of dissolved $\mathrm{Ca}$ to $\mathrm{Mg}$ are similar solids in the non-glacial rivers from the western region, but the proglacial WR waters again have higher $\mathrm{Ca} / \mathrm{Mg}$ than the solids. (Fig 6B).

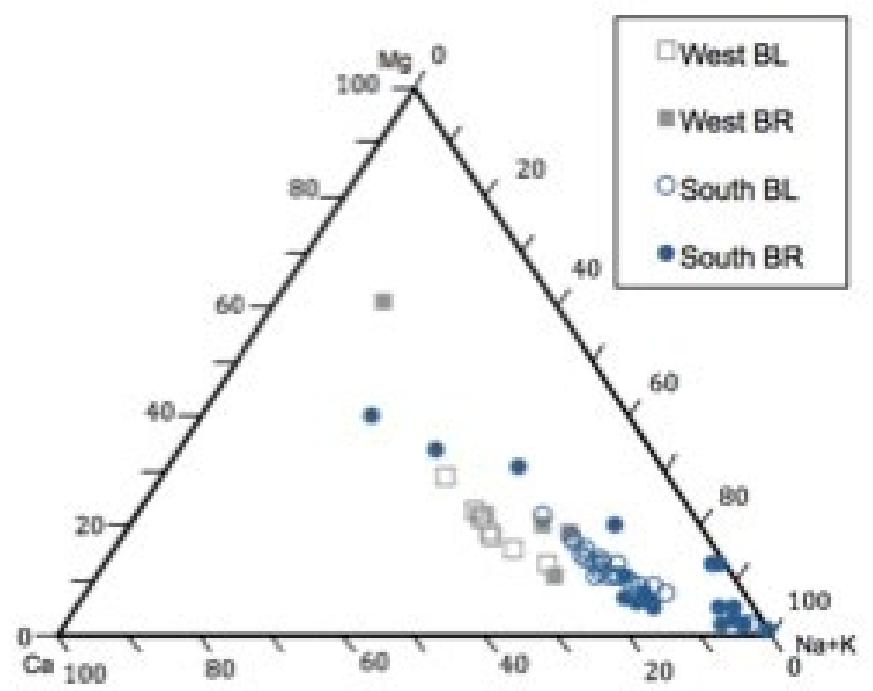

Figure 5. Ternary diagram of relative proportions of $\mathrm{Ca}, \mathrm{Mg}$ and $\mathrm{Na}+\mathrm{K}$ for southern (circles) and western (squares) bedload $(\mathrm{BL})$ and bedrock $(\mathrm{BR})$. 

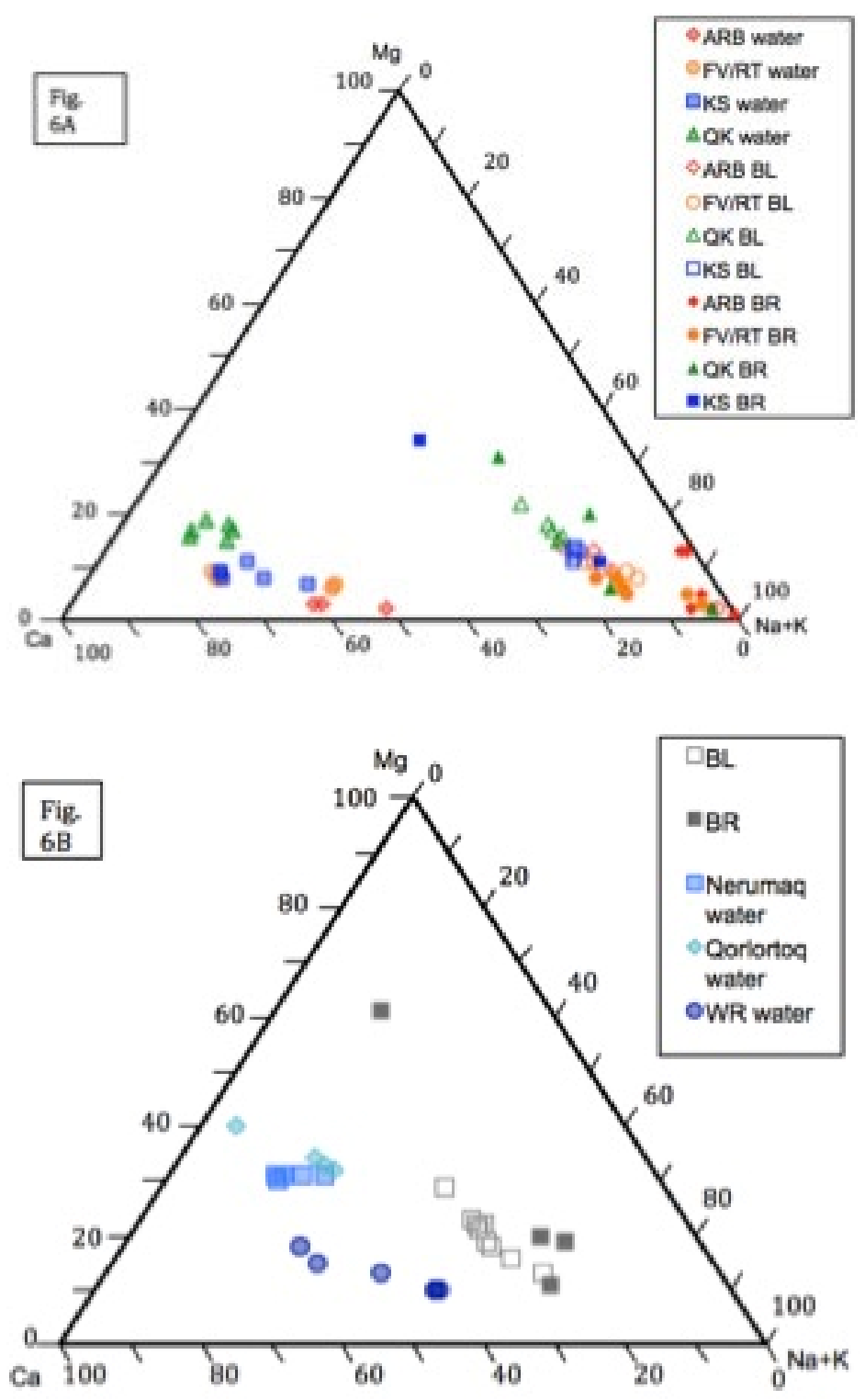

Figure 6. Ternary diagram of relative proportions of $\mathrm{Mg}, \mathrm{Ca}$ and $\mathrm{Na}+\mathrm{K}$ for water, $\mathrm{BR}$, and $\mathrm{BL}$ for $\mathrm{A}$ ) five watersheds in the Narsarsuaq (southern) region; symbols: light fill = water, no fill = bedload, dark fill = bedrock, and B) three watersheds in the western transect: symbols: semi-filled = water, open squares =bedload, solid squares $=$ bedrock.

Within the southern region, waters from QK and KS have the lowest proportions and ARB waters have the highest proportions of Si (Fig. 7A). Within the western region, Qorlortoq waters have the lowest proportions of Si and WR waters generally have the highest proportions, which are similar to proportions in ARB waters. Nerumaq waters cover the full Si range between the two western watersheds (Fig. 7A). 


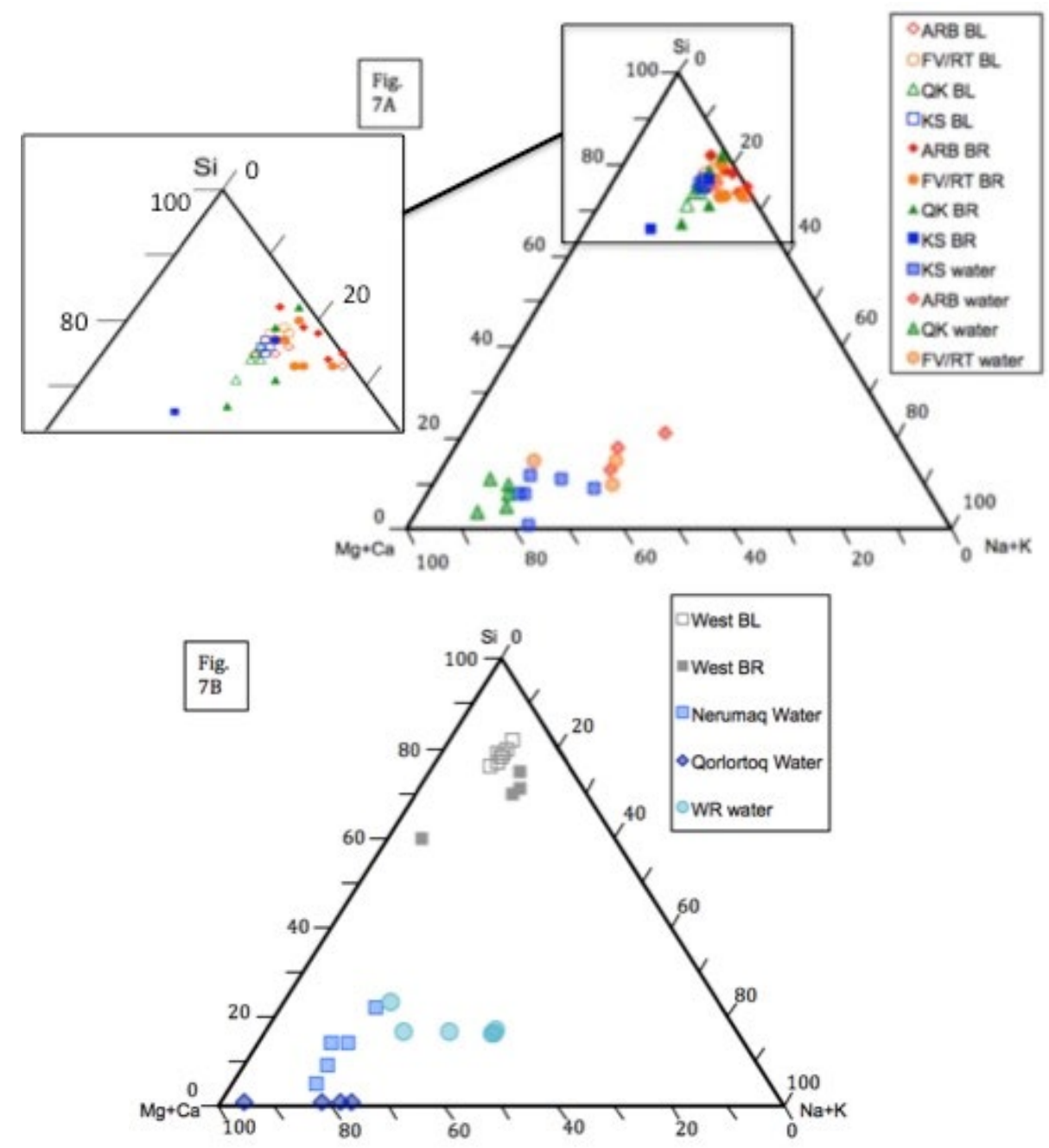

Figure 7. Ternary diagram showing the relative proportions of $\mathrm{Si}, \mathrm{Mg}+\mathrm{Ca}$ and $\mathrm{Na}+\mathrm{K}$ for water, $\mathrm{BR}$, and $\mathrm{BL}$ for $\mathrm{A}$ ) five watersheds in the southern region; symbols: light fill = water, no fill = bedload, dark fill = bedrock, and B) three watersheds in the western transect: symbols: semi-filled $=$ water, open squares $=$ bedload, solid squares $=$ bedrock.

\section{Discussion}

\section{Bedload vs. Bedrock Compositions}

As expected, the geochemical data illustrate clear lithological differences between the $\mathrm{KMB} / \mathrm{Gardar}$ rocks of the southern region and NMB rocks of western transect (Fig. 4A). The more gabbroic and syenitic lithologies are likely to weather more readily than the granites that are more common in the southern region (Fig. 4A). Due to the difficulty of obtaining representative bedrock samples for each watershed and a lack of knowledge about which lithologies exist under the ice sheet, bedload data were used to define a more representative composition of the entire drainage basin, while the specific bedrock compositions provide more information about end member compositions. Relative proportions of major cations demonstrate 
that the bedload samples do generally fall within the bedrock end members, particularly for the better-sampled southern region, and thus appear to integrate the regional bedrock (Figs. 5 and 6).

\section{Weathering extent within the southern region}

Several lines of evidence suggest the greatest maturity of weathering within the southern region occurs in the $\mathrm{ARB}$ and $\mathrm{FV}$ watersheds and the least mature weathering occurs in the $\mathrm{QK}$ watershed. The ARB and FV watersheds also include the greatest lithologic variability, including Gardar Province rocks, while QK and RT rocks generally have less weatherable, more granitic lithologies. In contrast to the variable bedrock, ARB bedload is one of the most silica-poor and FV bedload is one of the most silica-rich (Fig. 4B). The low $\% \mathrm{SiO}_{2}$ in $\mathrm{ARB}$ bedload compared to the bedrock suggests silica may have been stripped out by weathering, which is consistent with the high relative \% $\mathrm{Si}$ in $\mathrm{ARB}$ waters (Fig. 7). This watershed also has the lowest dissolved relative $\% \mathrm{Mg}+\mathrm{Ca}$ and the highest dissolved relative $\% \mathrm{Na}+\mathrm{K}$. These cation concentrations suggest that most of the easily weatherable carbonate in these rocks has been weathered away and more mature silicate weathering is occurring

QK also has relatively high $\% \mathrm{SiO}_{2}$ in the bedrock and low $\% \mathrm{SiO}_{2}$ bedload, but in this watershed the relative $\% \mathrm{Si}$ in the water is low. The QK waters also have the highest relative $\% \mathrm{Mg}+\mathrm{Ca}$ and lowest relative $\% \mathrm{Na}+\mathrm{K}$ of all the southern watersheds (Fig. 6A). These chemical variations suggest less mature weathering with continuing contributions from carbonates that release $\mathrm{Ca}+\mathrm{Mg}$ into the $\mathrm{QK}$ waters. The $\mathrm{KS}$ waters plot between these two end members, suggesting intermediate weathering maturity.

$\mathrm{Na}+\mathrm{K}$ are the cations most easily weathered from silicate rocks and are commonly the primary variable in chemical indices of weathering (e.g., Price and Velbel, 2003). The percent difference between the $\% \mathrm{Na}+\mathrm{K}$ in the bedload compared to the $\% \mathrm{Na}+\mathrm{K}$ in the associated water sample (Fig. 8) therefore provides a technique to compare weathering maturity between watersheds that takes into account the starting rock composition. A smaller difference in the $\% \mathrm{Na}+\mathrm{K}$ in the solid and water samples indicates a greater contribution of $\mathrm{Na}+\mathrm{K}$ to the water from weathering, and therefore more mature silicate weathering. In other words, the water chemistry looks more like the bulk rock chemistry, suggesting greater chemical weathering of the major rock-forming silicate minerals. The difference between the $\% \mathrm{Na}+\mathrm{K}$ in the bedload and water is smallest in ARB waters and similar to FV, again suggesting these watersheds are undergoing the most mature weathering. QK waters have the greatest difference between 
$\% \mathrm{Na}+\mathrm{K}$ in bedload and water, suggesting it is undergoing the least mature weathering (Fig. 8). This ranking of weathering maturity correlates with the $\mathrm{Si}$ and $\mathrm{Mg}+\mathrm{Ca}$ results described above. Based on this technique, RT and KS watersheds have intermediate weathering maturity that falls closest to the low maturity end of the range (Fig. 8). Thus, the basic lithology, relative \% $\mathrm{Si}$, relative $\% \mathrm{Mg}+\mathrm{Ca}$, and $\% \mathrm{Na}+\mathrm{K}$ data all indicate that the southern watersheds can be ranked $\mathrm{ARB}, \mathrm{FV}, \mathrm{KS}, \mathrm{RT}$, and QK in order from most weathered to least weathered.

\section{Evidence of chemical weathering extent between southern and western regions}

Scribner et. al. (2015) used chemical variations in the watersheds, including Sr isotopes, to determine that in the non-glacial watersheds the coastal Nerumaq region have experienced more mature weathering compared to the inland Qorlortoq watershed. A comparison between these non-glacial western watersheds and the southern region illustrates a distinct difference in the dissolved proportions of $\mathrm{Ca}$ and $\mathrm{Mg}$. The relative proportions of $\mathrm{Ca}$ to $\mathrm{Mg}$ in the non-glacial western waters are approximately the same as the bedload and bedrock (Fig. 6). In contrast, in the southern region all of the water samples are enriched in Ca relative to bedload/bedrock samples from the same location, suggesting preferential weathering of trace calcite. This suggests less extensive/less mature weathering in the southern deglaciated watersheds.

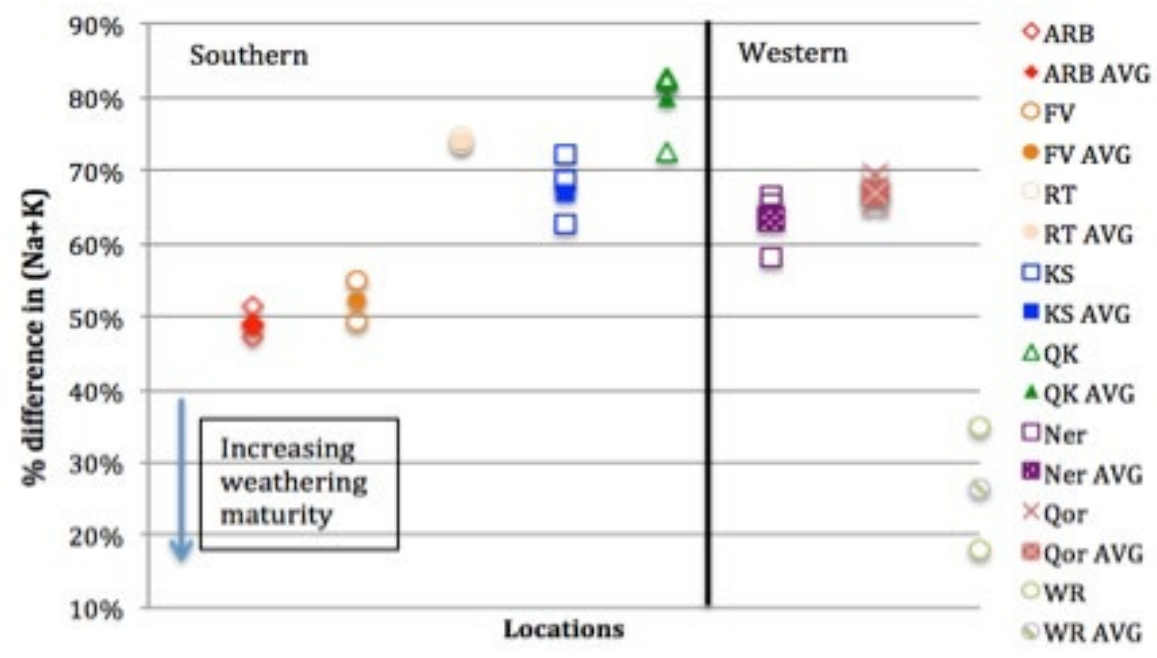

Figure 8. Calculated percent difference of $\% \mathrm{Na}+\mathrm{K}$ from bedload to waters using $\left[(\% \mathrm{Na}+\mathrm{K})_{\text {waters }}\right.$ $\left.(\% \mathrm{Na}+\mathrm{K})_{\mathrm{BL}}\right] /(\% \mathrm{Na}+\mathrm{K})_{\mathrm{BL}}$. A smaller percent difference reflects greater weathering of silicates in the stream water. Open symbols- data for individual samples, solid and semi-solid symbols - average value for each watershed.

In contrast, the relative dissolved $\% \mathrm{Si}$ data have a similar range of values in both regions, suggesting similar weathering maturities. These cation-dependent differences in perceived 
weathering maturity between the two regions may be lithologically controlled and suggest difference in dissolved Si between watersheds may depend on regional geology and cannot be used to compare the maturity of weathering between regions. The variation in weathering maturity derived from dissolved relative $\% \mathrm{Si}$, however, are consistent with data from other cations. Nerumaq and ARB have the highest dissolved \%Si for non-glacial streams, which suggests they are the most weathered watersheds for each region. QK and Qorlortoq waters have the lowest relative $\% \mathrm{Si}$, which suggests they represent the least mature weathering for each region. The proglacial streams in the two regions have different behavior compared to the nonglacial streams. WR in the western transect has the highest dissolved \% $\mathrm{Si}$, implying the most mature weathering, while $\mathrm{KS}$ has some of the lowest \% $\mathrm{Si}$ and apparently lower weathering maturity that several of the non-glacial systems.

Another way to compare the two regions is to use the $\% \mathrm{Na}+\mathrm{K}$ differences between bedload and waters (Fig. 8). This technique suggests more nuanced differences between the two regions. The southern watersheds show a greater overall range in weathering maturity for deglaciated watersheds, while the variation in deglaciated western watersheds is small. The proglacial WR has the highest weathering overall. In contrast, the proglacial KS has relatively low weathering maturity comparable to several of the deglaciated watersheds. The very high rates of weathering for WR compared to KS are associated with high dissolved organic matter (DOC) concentrations in the water discharging from the ice sheet (A. Pain, personal comm). This relationship indicates that degradation of organic matter under the ice, possibly catalyzed by microbial activity, may be an important driver of weathering in proglacial systems.

As indicated by the other chemical comparisons, QK is undergoing the least mature weathering in both regions based on $\% \mathrm{Na}+\mathrm{K}$. This is interesting because $\mathrm{QK}$ has some of the oldest moraine exposure ages and it is in the high precipitation, southern climate regime; two factors believed to enhance chemical weathering rates. The QK watershed is located at a higher elevation than the other non-glacial watersheds, and the elevation may impact the precipitation in this specific area. There are no meteorological data to confirm this idea; however, in contrast to the other southern watersheds, the upper portion of QK has very sparse vegetation. The vegetation increases a bit downstream, but still remains sparse compared to ARB, RT and FV. This lack of vegetation could be linked to low concentrations of soil $\mathrm{CO}_{2}$ that may impact weathering maturity. 
Lithology may also play a role in the wide range of apparent weathering maturity in the southern compared to the western deglaciated watershed. Lithology is quite uniform across the western region, but more variable in the southern region where lithology ranges from less weatherable granites in QK and RT to more easily weathered syenites in ARB and FV. The similarity in the extent of weathering based on $\% \mathrm{Na}+\mathrm{K}$ in bedload and water between $\mathrm{KS}$ and RT in the south and Nerumaq and Qorlortoq in western occurs despite higher precipitation and warmer temperatures in the south, suggesting the lithologic control is more important than climate. One possibility is that the climatic differences between the western and southern regions are small relative to variations between high latitude and mid-latitude or tropical sites. Under these conditions, lithologic variations and DOC concentrations may play a more important role in governing the weatherability of the rock and the availability of weathering acids.

\section{Conclusions}

Comparisons between relative $\% \mathrm{Mg}+\mathrm{Ca}$ and $\% \mathrm{Si}$ in stream waters and $\% \mathrm{Na}+\mathrm{K}$ in bedload versus water are interpreted in terms of differences in the maturity of chemical weathering between watersheds in the western transect and southern study areas of Greenland, as well as differences within each of those regions. In general, the evaluation of the stream water, bedload, and bedrock chemistry indicate that the bedload samples represent a basin-wide mixture of bedrock sources, potentially including sources from under the ice in proglacial systems. The chemistry of the waters suggest the proglacial WR watershed is experiencing more mature/more extensive weathering than the other watersheds, which may be driven by microbial reactions and high concentrations of DOC preserved in soils under the ice. These reactions provide acids that enhance chemical weathering. In contrast, the proglacial KS waters contain much lower concentrations of DOC.

The relative $\% \mathrm{Mg}+\mathrm{Ca}$ in non-glacial streams suggests greater input from carbonate minerals that tend to weather quickly in the southern watersheds, and thus less mature weathering in the south. In contrast, dissolved \% Si has a similar range in western and southern watersheds and can be broken down into watersheds with the least to most mature weathering that is consistent with results from the difference in the $\% \mathrm{Na}+\mathrm{K}$ in the waters versus the bedload. Both the dissolved $\% \mathrm{Si}$ and $\% \mathrm{Na}+\mathrm{K}$ techniques indicate weathering maturity increases from $\mathrm{QK}$ to RT to FV to ARB in the south, and Qorlortoq is less weathered than Nerumaq in the west. The $\% \mathrm{Na}+\mathrm{K}$ data also suggest a wider range of weathering intensities in the deglacial southern 
watersheds that includes estimates of more mature weathering in ARB and FV, similar weathering maturity in $\mathrm{KS}$ and $\mathrm{RT}$ and less mature weathering in QK compared to the two western deglacial watersheds.

The differences in the interpretations of the maturity of weathering based on different cations likely reflects the control of mineralogy, and therefore lithology, on chemical weathering. Lithology also appears to be a major control on the maturity of weathering because the southern region, which experiences much higher precipitation and warmer temperatures, does not consistently record more mature weathering. Instead the regions containing more granitic/less weatherable lithologies appear to be the least weathered, while regions with more syenitic rocks record the most mature weathering. This is particularly pronounced for the QK watershed, which is located in the high rainfall/higher temperature southern region and has some of the older moraine exposure ages, yet records some of the lowest weathering maturity. One explanation may be that the climatic differences and differences in moraine ages between these regions is relatively small and therefore lithology plays a dominant role in controlling chemical weathering.

\section{Acknowledgements}

We'd like to thank Jon Martin for helpful discussions; the Greenland field party, Jon Martin, Shaily Rahman, and Andrea Pain, who helped with sample collection; Andrea Pain for providing solute chemistry for waters; and Ann Heatherington for assistance with XRF. This project was funded by NSF grant OPP-1603452 and the University Scholars Program at UF. Samples were collected under Bureau of Minerals and Petroleum, Government of Greenland, Export license 027/2013.

\section{References}

Anderson, S.P., 2007, Biogeochemistry of glacial landscape systems. Annu Rev Earth Pl Sc, 35:1, 375399.

Anderson, S.P., Drever J. I., Frost C. D., and Holden P., 2000, Chemical weathering in the foreland of a retreating glacier. Geochim Cosmochim Acta, 64, 1173-1189.

Bhatia M.P., Kujawinski E.B., Das S.B., Breier C.F., Henderson P.B. and Charette M.A., 2013, Greenland meltwater as a significant and potentially bioavailable source of iron to the ocean. Nat. Geosci, 6, 274-278.

Collazo, D.F., Martin, J.B., Deuerling, K.M., 2015, Chemical composition and weathering of bedrock in the deglaciated portion of western Greenland, (Undergraduate thesis): University of Florida.

Deuerling, K.M., 2016, Continental ice sheet retreat, chemical weathering, and solute and isotope fluxes: 
examples from western Greenland, (Dissertation): University of Florida.

Foster, G.L. and Vance D., 2006, Negligible glacial-interglacial variation in continental chemical weathering rates. Nature, 444, 918-921.

Paslick, C.R., Halliday, A.N., Davies, G.R., Mezger, K., Upton, B.G.J., 1993, Timing of proterozoic magmatism in the Gardar Province, southern Greenland. Geol Soc Am Bull, 105 (2), 272-278.

Price, J.R., and Velbel, M.A., 2003, Chemical weathering indices applied to weathering profiles developed on heterogeneous felsic metamorphic parent rocks. Chem Geol, 202, 397-416.

Reyes, A.V., Carlson, A.E., Beard, B.L., Hatfield, R.G., Stoner, J.S., Winsor, K., Welke, B., Ullman, D.J., 2014, South Greenland ice-sheet collapse during marine isotope stage 11. Nature, 510, 525-528.

Scribner, C.A., Martin, E.E., Martin, J.B., Deuerling, K.M., Collazo, D.F., Marshall, A.T. 2015, Controls on weathering in deglaciated watersheds of western Greenland. Geochim Cosmochim Acta, 170, 157-172.

Tranter, M., 2003, Geochemical weathering in glacial and proglacial environments. Treatise on Geochemistry, 5, 189-205.

White, L.F., Bailey, I., Foster, G.L., Allen, G., Kelley, S.P., Andrews J.T., Hogan, K., Dowdeswell, J.A., Storey, C.D., 2016, Tracking the provenance of Greenland-sourced, Holocene aged, individual sand-sized ice-rafted debris using the $\mathrm{Pb}$-isotope compositions of feldspars and 40Ar/39Ar ages of hornblendes. Earth Planetary Sci Lett, 433, 192-203.

Wimpenny, J., James R. H., Burton K. W., Gannoun A., Mokadem F. and G1ÅLslason S. R., 2010, Glacial effects on weathering processes: new insights from the elemental and lithium isotopic composition of west Greenland rivers. Earth Planet Sci Lett, 290, 427-437. 